\title{
METODE SPATIAL DURBIN MODEL UNTUK ANALISIS DEMAM BERDARAH DENGUE DI KABUPATEN BANTUL
}

\author{
Marthin Luter Laia ${ }^{1}$, Rahmat Deswanto ${ }^{2}$, Erma Shofi Utami ${ }^{3}$, Rokhana Dwi Bekti ${ }^{4}$ \\ ${ }^{1}$ Jurusan Statistika, FST, Institut Sains \& Teknologi AKPRIND Yogyakarta, Indonesia

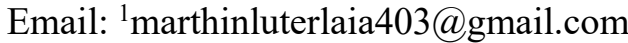 \\ ${ }^{2}$ Jurusan Statistika, FST, Institut Sains \& Teknologi AKPRIND Yogyakarta, Indonesia \\ Email: 22deswantorahmat@gmail.com \\ ${ }^{3}$ Jurusan Statistika, FST, Institut Sains \& Teknologi AKPRIND Yogyakarta, Indonesia \\ Email: ${ }^{3}$ rmashofi175@gmail.com \\ ${ }^{4}$ Jurusan Statistika, FST, Institut Sains \& Teknologi AKPRIND Yogyakarta, Indonesia \\ Email: ${ }^{4}$ rokhana@akprind.ac.id
}

\begin{abstract}
ABSTRAK
Dengue Hemorrhagic Fever (DHF) is an infectious disease caused by the dengue virus which is transmitted through the bite of the Aedes aegepty and Aedes albopictus mosquitoes which are widespread in homes and public places throughout the territory of Indonesia. The high number of DHF cases in Bantul Regency, Indonesia is an indication that eradication of Aedes aegepty mosquitoes and Aedes albopictus mosquitoes has not succeeded in the Bantul Regency. Spatial Regression is an analysis that evaluates the relationship between one variable with several other variables by providing spatial effects in several locations that are the center of observation. Three type of models are Spatial Autoregressive Model (SAR), Spatial Error Model (SEM), and Spatial Durbin Model (SDM). This study uses secondary data in 2017 in Bantul Regency, Special Region of Yogyakarta, Indonesia. The dependent variable is DHF cases and the independent variables are medical personnel and health facilities in each sub-district. The spatial model used is SDM. Based on Moran's I test, there was a spatial autocorrelation about DHF among sub-district, so the spatial model can be used. The durbin spatial model gives the result that all estimation parameters in SDM model have $P$ value less than $\alpha=5 \%$, so that medical personnel and health facilities significantly affect dengue cases in Bantul Regency.
\end{abstract}

Keywords: dengue hemorrhagic fever, moran's I test, spatial durbin model

\section{PENDAHULUAN}

Deman Berdarah Dengue (DBD) merupakan penyakit infeksi yang disebabkan oleh virus dengue yang ditularkan melalui gigitan nyamuk Aedes aegepty dan Aedes albopictus yang tersebar luas di rumah-rumah dan tempat umum di seluruh wilayah Indonesia. Penyakit ini terutama menyerang anak yang ditandai dengan panas tinggi, pendarahan dan dapat mengakibatkan kematian serta menimbulkan wabah. Pada tahun 2017 jumlah kasus DBD di Kabupaten Bantul turun bila dibandingkan pada tahun 2016. Pada tahun 2016 terdapat 2442 kasus DBD di Kabupaten Bantul dengan Angka Kesakitan (IR) sebesar 2,62\%. Sedangkan 
pada tahun 2017 sebanyak 538 kasus DBD dengan Angka Kesakitan (IR) sebesar 0,55\% (Dinas Kesehatan Kabupaten Bantul Tahun 2018).

Mengetahui faktor-faktor yang mempengaruhi penyakit DBD merupakan hal penting untuk memberikan informasi dan sebagai jaminan hidup bagi masyarakat setempat untuk tetap tinggal di daerah tersebut. Selain itu, pemetaan penyebaran kasus DBD juga penting untuk memberikan informasi bagi masyarakat. Banyak metode statistik yang dapat digunakan untuk menganalisis penyakit DBD, faktor-faktor yang mempengaruhi DBD, dan penyebarannya di suatu lokasi. Penelitian oleh Suyasa, Putra, and Aryanta (2008) melakukan analisis hubungan faktor lingkungan dan perilaku masyarakat dengan keberadaan vektor demam berdarah dengue (DBD) di wilayah kerja puskesmas I Denpasar Selatan. Sintorini (2007) melakukan analisis pengaruh iklim terhadap kasus demam berdarah dengue. Candra (2010) melakukan analisis demam berdarah dengue: epidemiologi, patogenesis, dan faktor risiko penularan. Waris and Yuana (2013) melakukan analisis pengetahuan dan perilaku masyarakat terhadap demam berdarah dengue di Kecamatan Batulicin Kabupaten Tanah Bumbu Provinsi Kalimantan Barat. Kusuma and Sukendra (2016) melakukan analisis spasial kejadian demam berdarah dengue berdasarkan kepadatan penduduk. Rahman, Rahim, and Mallongi (2018) juga melakukan analisis risiko kejadian demam berdarah di Provinsi Bone Sulawesi Selatan menggunakan model geostatistik spasial temporal. Huang et al. (2018) menggunakan metode pengelompokan spasial untuk kejadian demam berdarah dan hubungannya dengan kehijauan di sekitarnya. Berdasarkan penelitian-penelitian tersebut, dapat diketahui bahwa metode statistika spasial memberikan peranan penting. Dengan demikian, penelitian ini menggunakan salah satu metode spasial untuk mengetahui faktor-faktor yang mempengaruhi DBD di Kabupaten Bantul.

Analisis regresi spasial merupakan pengembangan dari metode regresi linier klasik untuk mengetahui pengaruh suatu variabel independen terhadap variabel dependen dengan memperhatikan pengaruh spasial. Pengembangan itu berdasarkan hukum Tobler. Hukum pertama tentang geografi yang menjadi salah satu dasar pengembangan analisis spasial dikemukakan oleh Tobler yang menyatakan "bahwa segala sesuatu saling berhubungan satu dengan yang lainnya, tetapi sesuatu yang lebih dekat akan mempunyai pengaruh yang lebih daripada sesuatu yang jauh". Ini berarti adanya pengaruh tempat atau spasial pada data yang dianalisis (Anselin, 2001) Metode spasial yang digunakan dalam penelitian ini adalah regresi Spatial Durbin Model (SDM). Model SDM adalah kasus khusus dari Spatial Autoregressibe Model (SAR) yaitu dengan menambahkan pengaruh lag pada variabel independen sehingga ditambahkan spasial lag pada model (Anselin, 2001). 
Untuk mengetahui atau mengidentifikasi faktor-faktor yang mempengaruhi penyakit Demam Berdarah Dengue maka Analisis Regresi Spasial menggunakan metode Spatial Durbin Model (SDM) dapat digunakan untuk memetakan penyebaran kasus DBD sehingga dapat diperoleh solusi untuk mengurangi kasus DBD di Kabupaten Bantul. Dengan hasil ini maka dapat diketahui faktor-faktor penyebab penyakit Demam Berdarah Dengue (DBD) serta persentase kasus Demam Berdarah Dengue (DBD) di Kabupaten Bantul.

\section{METODE PENELITIAN}

Data yang digunakan dalam penelitian adalah data sekunder yang didasarkan pada tahun 2017 dengan 17 Kecamatan di Kabupaten Bantul seperti terlihat pada Gambar 1. Data diperoleh dari Badan Pusat Statistik Kabupaten Bantul, DIY, Indonesia. Nama-nama 17 Kecamatan tersebut adalah 1) Kasihan, 2)Banguntapan, 3) Sedayu, 4) Piyungan, 5) Sewon, 6) Pajangan, 7) Pleret, 8) Bantul, 9) Dlingo, 10) Jetis, 11) Pandak, 12) Imogiri, 13) Bambanglipuro, 14) Srandakan, 15) Pundong, 16) Sanden, dan 17) Kretek.

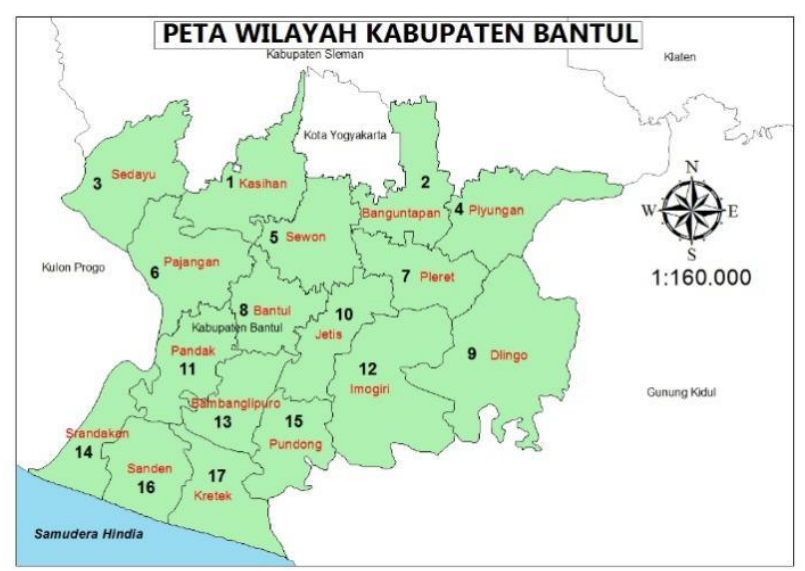

Gambar 1. Peta Kabupaten Bantul

Adapun variabel yang digunakan dalam penelitian terdiri dari:

1. Variabel dependen $(Y)$ dalam penelitian ini yaitu persentase kasus DBD menurut kecamatan.

2. Variabel independen $(X)$ yang digunakan sebanyak dua variabel, yaitu jumlah tenaga medis tiap kecamatan $\left(\mathrm{X}_{1}\right)$ dan jumlah fasilitas kesehatan tiap kecamatan $\left(\mathrm{X}_{2}\right)$.

Tahapan analisis data menggunakan model regresi spasial berbasis area adalah sebagai berikut:

1. Analisis deskriptif, pola spasial dan peta tematik.

2. Menyusun matriks pembobot spasial menggunakan.

3. Melakukan uji Morans'I. 
Hipotesis yang digunakan adalah

$\mathrm{H}_{0}: \mathrm{I}=0$ (tidak terdapat auto korelasi kejadian antar lokasi)

$\mathrm{H}_{0}: \mathrm{I} \neq 0$ (terdapat auto korelasi kejadian antar lokasi)

4. Uji dependensi spasial dengan uji Lagrange Multiplier(LM).

5. Pemodelan Spasial SAR, SEM dan SDM

6. Perbandingan model spasial dengan kriteria nilai AIC.

7. Kesimpulan.

Analisis spasial adalah metode yang menggambarkan bagaimana fenomena geografis terdistribusi dan bagaimana itu membandingkan dengan fenomena lain (Suryowati, Bekti, \& Faradila, 2018; Triliani \& Bekti, 2017). Sehingga regresi spasial digunakan untuk mengetahui hubungan antara variabel dependen dan variabel independen dengan mempertimbangkan keterkaitan pengamatan satu dengan yang lain antar wilayahdengan unsur tata letak geografis. Pengamatan yang dikumpulkan bisa berasal dari suatu titik atau area di suatu wilayah tertentu. Dalam analisis regresi spasial terdapat model spasial yang dapat memberikan gambaran tentang hubungan antara variabel dependen dan independen yang memperhitungkan tata letak geografis. Menurut Anselin (2001) model umum regresi spasial dapat ditunjukkan pada persamaan sebagai berikut:

$$
\begin{aligned}
& y=\rho W_{1} y+X \beta+u \\
& y=\left(I-\rho W_{1}\right)^{-1} X \beta+\left(I-\rho W_{1}\right)^{-1}\left(I-\lambda W_{2}\right)^{-1}+\varepsilon \\
& \text { dimana } u=\lambda W_{2}+\varepsilon ; \varepsilon \sim \mathrm{N}\left(0, \sigma^{2} \mathrm{I}\right)
\end{aligned}
$$

Model u mempunyai error yang berdistribusi normal dengan mean nol dan varians $\sigma^{2} I$. Parameter yang di estimasi adalah $\beta, \rho$ dan $\lambda . \rho$ adalah parameter koefisien spasial lag variabel dependen dan $\lambda$ adalah parameter koefisien spasial lag pada error. Pengaruh spasial antar lokasi dalam model dibentuk dalam matrik pembobot $w_{1}, w_{2}$ yang berukuran $n \times n$. Dari model tersebut dapat didetailkan menjadi Spatial Autoregressive Model (SAR), Spatial Error Model (SEM) dan Spasial Durbin Model (SDM).

Menurut Anselin (2001) SAR adalah model yang mengkombinasikan model regresi sederhana dengan lag spasial pada variabel dependen artinya spasial lag muncul saat nilai observasi variabel dependen pada suatu lokasi berkorelasi dengan nilai observasi variabel dependen di lokasi sekitarnya. Model spasial autoregressive terbentuk apabila $w_{2}=$ 0 dan $\lambda=0$, sehingga model ini mengasumsikan bahwa proses autoregressive hanya pada variabel dependen. Model umum SAR ditunjukan oleh persamaan sebagai berikut:

$$
y_{i}=\boldsymbol{\rho} \sum_{j=1}^{n} \boldsymbol{W}_{i j} y_{j}+\sum_{k=1}^{n} X_{i k} \beta_{i k}+\varepsilon_{i}
$$


Dengan $\varepsilon_{i} \sim N\left(0, \sigma^{2}\right)$

Model SAR dalam bentuk matrik:

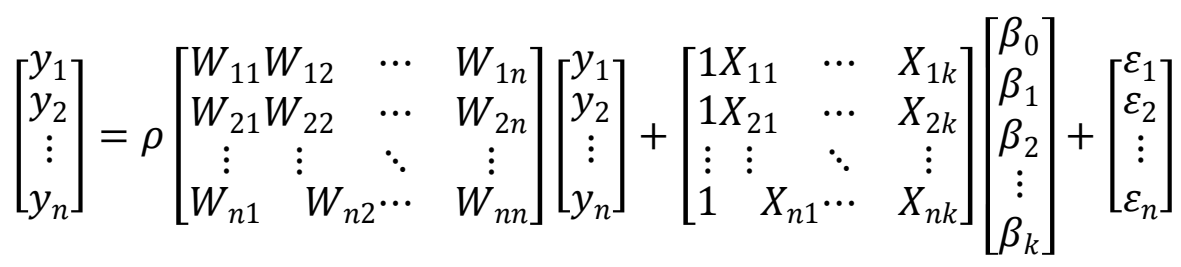

Jika ditulis dalam bentuk matrik tersebut ditulis dalam model persamaan adalah sebagai berikut:

$$
\boldsymbol{y}=\rho W_{1 \mathrm{y}}+\boldsymbol{X} \boldsymbol{\beta}+\varepsilon
$$

Spatial ErrorModel muncul saat nilai error pada suatu lokasi berkorelasi dengan nilai error di lokasi sekitarnya SEM terbentuk apabila $W_{1}=0$ dan $\rho=0$, sehingga model ini mengasumsikan bahwa proses autoregressive hanya pada error model. Model umum SEM ditunjukan dengan bentuk persamaan sebagai berikut:

$$
y_{i}=\sum_{k=1}^{n} X_{i k} \beta_{i k}+\lambda \sum_{j=1}^{n} w_{i j} u_{j}+\varepsilon_{i}
$$

Dengan $\varepsilon_{i} \sim N\left(0, \sigma^{2}\right)$

Model SEM dalam bentuk matriks:

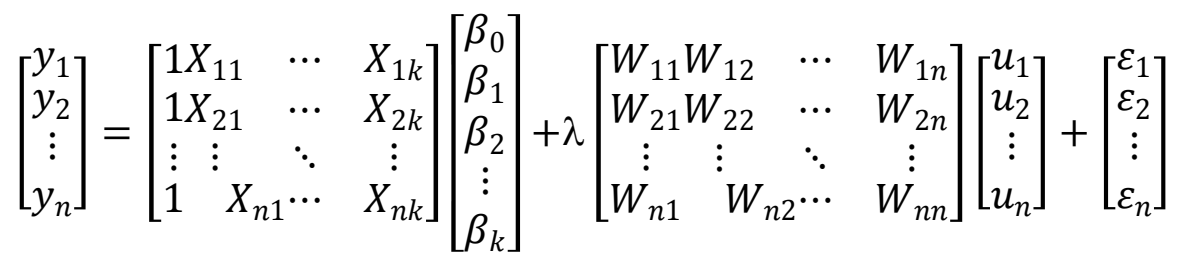

Jika dituliskan dalam bentuk persamaan adalah sebagai berikut:

$$
\begin{aligned}
& \boldsymbol{y}=\mathrm{X} \boldsymbol{\beta}+\lambda \boldsymbol{W}_{2} \mathrm{u}+\boldsymbol{\varepsilon} \\
& \boldsymbol{\varepsilon} \sim \mathrm{N}\left(0, \sigma^{2} \mathrm{I}\right)
\end{aligned}
$$

Spatial Durbin Model (SDM) merupakan kasus khusus dari SAR yaitu dengan menambahkan pengaruh lag pada variabel independen, sehingga ditambahkan spasial lag pada model. Pembobotan dilakukan pada variabel independen maupun dependen. Bentuk model SDM adalah sebagai berikut (Anselin, 1988)\& (Rokhana, 2017):

$$
\begin{array}{r}
\boldsymbol{Y}=\rho \boldsymbol{W}_{\mathbf{1}} \boldsymbol{Y}+\boldsymbol{\beta}_{\mathbf{0}}+\boldsymbol{X} \boldsymbol{\beta}_{\mathbf{1}}+\boldsymbol{W}_{\mathbf{1}} \boldsymbol{X} \boldsymbol{\beta}_{\mathbf{2}}+\boldsymbol{\varepsilon} \\
\boldsymbol{\varepsilon} \sim N\left(0, \sigma^{2} \boldsymbol{I}\right)
\end{array}
$$




$$
\boldsymbol{\beta}_{\mathbf{1}}=\left[\begin{array}{c}
\beta_{11} \\
\beta_{12} \\
\beta_{13} \\
\vdots \\
\beta_{1 k}
\end{array}\right], \boldsymbol{\beta}_{\mathbf{2}}=\left[\begin{array}{c}
\beta_{21} \\
\beta_{22} \\
\beta_{23} \\
\vdots \\
\beta_{2 k}
\end{array}\right]
$$

Estimasi parameter SDM menggunakan Maximum Likelihood Estimation, dengan persamaan sebagai berikut:

$$
\begin{aligned}
& Y=\rho W_{1} Y+\beta_{0}+X \beta_{1}+W_{1} X \beta_{2}+\varepsilon \\
& Y=\left(1-\rho W_{1}\right)^{-1} Z \beta+\varepsilon \\
& \text { dengan } \\
& Y \sim \boldsymbol{N}\left(1-\rho W_{1}\right)^{-1} Z \beta, \sigma^{2} I
\end{aligned}
$$

Estimasi $\beta$ adalah:

$$
\widehat{\boldsymbol{\beta}}=\left(Z^{T} Z\right)^{-1} Z^{T}\left(1-\rho W_{1}\right) \boldsymbol{y}
$$

Dengan $\mathrm{Z}=\left[\mathbf{I} \mathbf{X} \mathbf{W}_{\mathbf{1}} \mathrm{X}\right]$

Penelitian yang telah menggunakan model SDM diantaranya penelitian oleh I.R Ramadani, R. Rahmawati, A. Hoyyi (2013) dengan judul Analisis Faktor-Faktor yang Mempengaruhi Gizi Buruk Balita di Jawa Tengah dengan Metode Spatial Durbin Model. Model umum SDM ditunjukan dengan bentuk persamaan sebagai berikut :

$$
\boldsymbol{Y}=\rho \boldsymbol{W} \boldsymbol{Y}+\boldsymbol{\alpha}+\boldsymbol{X} \boldsymbol{\beta}+\boldsymbol{W} \boldsymbol{X} \boldsymbol{\theta}+\boldsymbol{\varepsilon}
$$

Dalam analisis spasial perlu identifikasi auoto korelasi antar wilayah. Pengujian efek spasial mengunakan uji Morans'I digunakan untuk pengujian dalam melihat auto korelasi spasial (Anselin, 2001). Auto korelasi spasial adalah penilaian korelasi antar pengamatan atau lokasi pada suatu variabel berdasarkan letak geografis. Jika pengamatan $X_{1}, X_{2}, \ldots, X_{n}$ menunjukkan saling ketergantungan terhadap ruang atau lokasi, maka data tersebut dikatakan berkorelasi secara spasial. Penghitungan auto korelasi spasial menggunakan rumus Moran's I dengan matriks pembobot dalam bentuk matriks yang sudah terstandarisasi adalah sebagai berikut:

$$
I=\frac{n \sum_{i=1}^{n} \sum_{j=1}^{n} w_{i j}^{*}\left(X_{i}-\bar{X}\right)\left(X_{j}-\bar{X}\right)}{\sum_{i=1}^{n} \sum_{j=1}^{n} w_{i j}^{*}\left(X_{i}-\bar{X}\right)}
$$

Keterangan:

$I$ : Indeks Moran (Moran's I )

$n$ : banyaknya lokasi kejadian 
$X_{i}$ : nilai pada lokasi i

$X_{j}$ : nilai lokasi pada $\mathrm{j}$

$\bar{X}$ : rata-rata dari jumlah variabel atau nilai

$w_{i j}^{*}$ : elemen pada pembobot terstandarisasi antara daerah $\mathrm{i}$ dan $\mathrm{j}$

\section{HASIL DAN PEMBAHASAN}

Persentase penduduk yang mempunyai keluhan kesehatan selama sebulan terakhir di Indonesia pada tahun 2016 adalah $28.53 \%$ dan pada tahun 2017 meningkat menjadi $28.62 \%$. Data Kementerian Kesehatan RI menyatakan bahwa selama tahun 2017 kejadian DBD di Indonesia adalah 68.407 kasus. Wilayah yang memiliki kejadian DBD tertinggi adalah di Provinsi Jawa Barat dengan jumlah 10.016 kasus. Sementara itu, DIY memiliki 1.642 kasus dengan Incidence Rate 43,65 per 100.000 penduduk yang berada di peringkat 6 dari 34 Propinsi di DIY. Pada tahun 2017, Kabupaten Bantul memiliki jumlah kasus DBD tertinggi di DIY.

Penyebaran persentase kasus DBD di Kabupaten Bantul tahun 2017 disajikan pada Gambar 2. Persentase kasus DBD yang tinggi menyebar di kecamatan-kecamatan yang berada di bagian tengah dan selatan. Terdapat 3 kecamatan yang memiliki persentase DBD tinggi yaitu Kecamatan Kretek, Bambanglipuro, dan Jetis yaitu masing-masing 0,089\%, 0,099\%, dan 0,085\%. Kecamatan yang memiliki persentase DBD paling rendah adalah Kecamatan Dlingo, yaitu $0,014 \%$.

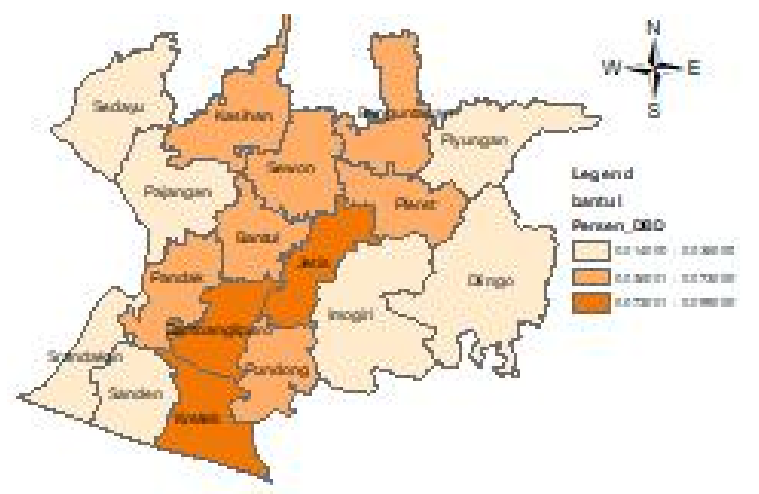

Gambar 2. Peta Penyebaran Persentase Kasus DBD di Kabupaten Bantul

Banyak hal yang mempengaruhi tingginya persentase kasus DBD. Pemerintah tentu terus berupaya untuk menyelesaikan permasalahan tersebut. Fasilitas kesehatan, seperti rumah sakit, puskesmas, klinik, tenaga medis dokter, perawat, dan sebagainya sangat memberikan peran penting untuk mengatasi permasalahan dan persentase menurunkan angka kasus DBD. Penelitian ini menggunakan data jumlah tenaga medis dan jumlah fasilitas kesehatan untuk 
mengetahui dampaknya terhadap kasus DBD di Kabupaten Bantul. Gambar 3 menunjukkan peta jumlah tenaga medis di setiap kecamatan. Wilayah yang berada di bagian utara, yaitu dekat dengan Kota Yogyakarta sebagai ibukota Provinsi DIY, memiliki jumlah tenaga medis yang tinggi. Kecamatan tersebut adalah Kecamatan Banguntapan. Begitu juga Kecamatan Bantul yang merupakan pusat pemerintahan. Sementara itu, Kecamatan Kretek yang berada di bagian paling selatan memiliki jumlah tenaga medis yang lebih rendah. Gambar 4 menunjukkan pola spasial jumlah fasilitas kesehatan di setiap kecamatan. Sama halnya dengan tenaga medis, wilayah yang berada di bagian utara dan pusat pemerintahan kabupaten memiliki jumlah fasilitas kesehatan yang tinggi.

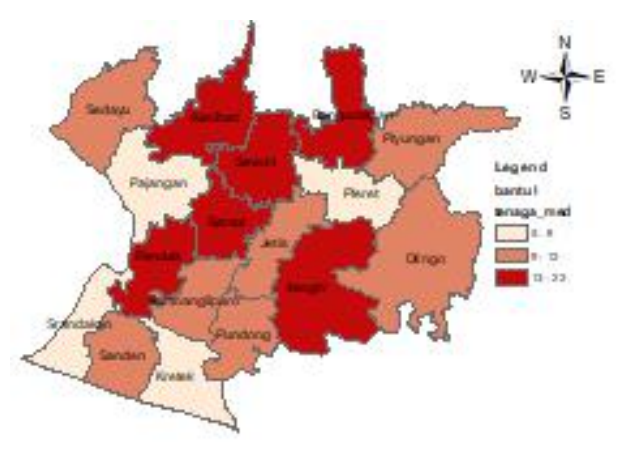

Gambar 3. Peta Pola Spasial Jumlah Tenaga Medis

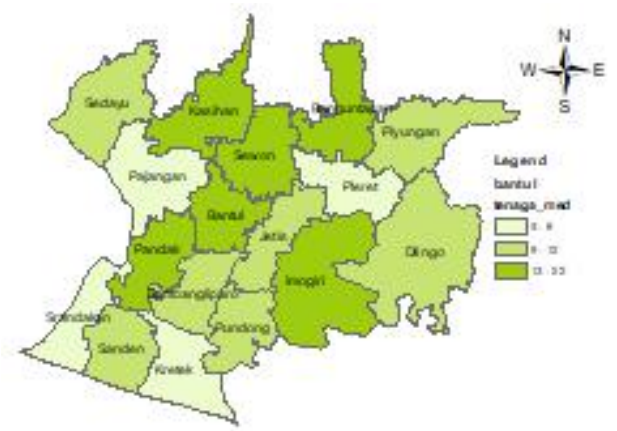

Gambar 4. Peta Pola Spasial Fasilitas Kesehatan

Apabila dilakukan eksplorasi pola hubungan antara fasilitas dengan kasus DBD di setiap kecamatan, dapat diketahui bahwa wilayah yang memiliki fasilitas kesehatan yang lebih sedikit maka jumlah kasus DBD akan tinggi. Sebagai contoh adalah Kecamatan Kretek dan Bambanglipuro. Sebaliknya, wilayah yang memiliki fasilitas kesehatan yang lebih tinggi maka jumlah kasus DBD akan rendah. Dengan demikian penelitian ini mengidentifikasi signifikansi pengaruh jumlah tenaga medis dan fasilitas kesehatan terhadap kasus DBD melalui pemodelan regresi. Model regresi yang digunakan adalah model spasial. 
Model regresi spaial digunakan karena terdapat indikasi adanya pengaruh lokasi wilayah terhadap penyebaran DBD. Seperti yang penelitian yang dilakukan oleh Suryowati, Bekti, dan Faradila (2018), dimana analisis kejadian DBD perlu menggunakan analisis spasial karena kasus DBD antar lokasi saling berhubungan. Saputro, Muhsinin, dan Widyaningsih juga menggunakan model spasial untuk analisis DBD. Brauer, Castillo-Chavez, dan Feng (2018) dalam bukunya Mathematical Models in Epidemiology juga menyebutkan bahwa model spasial akan terus berkembang dan memberikan banyak informasi terkait epidemiologi suatu penyakit. Seperti pada kasus DBD di Kabupaten Bantul, lokasi sangat mempengaruhi penyebarannya. Kecamatan-kecamatan yang jauh dari pusat fasilitas kesehatan utama, yang umumnya ada di pusat pemerintahan, maka cenderung memiliki resiko DBD tinggi. Masyarakat yang tinggal di daerah ini juga cenderung memiliki tingkat kesejahteraan yang rendah atau tingkat pendidikan dan pengetahuan tentang DBD yang rendah.

Pembuktian mengenai adanya pengaruh lokasi pada kasus DBD dan ada tidaknya hubungan DBD antar kecamatan dilakukan melalui uji Moran's I. Uji ini bertujuan untuk melihat auto korelasi spasial atau penilaian korelasi antar pengamatan atau lokasi pada suatu variabel berdasarkan letak geografis. Dalam hal ini tiap variabel akan dilihat auto korelasinya dan menggunakan hipotesis nol $\mathrm{I}=0$ (Tidak terdapat auto korelasi antar lokasi) dan hipotesis alternatif $\mathrm{I} \neq 0$ (terdapat auto korelasi antar lokasi). Hasil pengujian disajikan pada Tabel 2.

\begin{tabular}{cccc}
\multicolumn{4}{c}{ Tabel 2. Hasil Pengujian Morans'I } \\
\hline Variabel & Moran's I & E (I) & p-value \\
\hline $\mathrm{Y}$ & 0,3451 & $-0,0625$ & 0,0079 \\
$\mathrm{X}_{1}$ & 0,0051 & $-0,0625$ & 0,6585 \\
$\mathrm{X}_{2}$ & 0,1994 & $-0,0625$ & 0,0812 \\
\hline
\end{tabular}

Berdasarkan Tabel 2, dapat dilihat bahwa nilai p-value untuk variabel persentase kasus DBD lebih kecil dari taraf signifikansi $(\alpha) 5 \%$, sehingga $\mathrm{H}_{0}$ ditolak artinya terdapat auto korelasi spasial. Kasus DBD antar kecamatan di Kabupaten Bantul saling berhubungan. Lokasi sangat berpengaruh pada penyebaran DBD. Suatu kecamatan akan memiliki jumlah kasus DBD tinggi, jika bertetanggaan atau berdekatan dengan kecamatan lain yang memiliki jumlah kasus DBD tinggi juga. Begitu juga sebaliknya, suatu kecamatan akan memiliki jumlah kasus DBD rendah, jika bertetanggaan atau berdekatan dengan kecamatan lain yang memiliki jumlah kasus DBD rendah juga. Sedangkan, uji Moran's I pada variabel jumlah tenaga medis $\left(\mathrm{X}_{1}\right)$ dan fasilitas kesehatan $\left(\mathrm{X}_{2}\right)$ memberikan hasil bahwa tidak terdapat autokorelasi spasial antar kecamatan. 
Analisis selanjutnya adalah menggunakan model regresi spasial untuk mengetahui apakah jumlah tenaga medis $\left(\mathrm{X}_{1}\right)$, fasilitas ksehatan $\left(\mathrm{X}_{2}\right)$, serta lokasi memberikan pengaruh pada kasus DBD di Kabupaten Bantul. Model regresi spasial yang digunakan adalah Spatial Autoregressive Model (SAR), Spatial Error Model (SEM), dan Spatial Durbin Model (SDM). Tujuan penggunaan tiga model tersebut adalah untuk memberikan gambaran pola hubungan dengan lebih luas dan memilih model yang terbaik untuk pemodelan kasus DBD.

Langkah awal pada pemodelan adalah melakukan uji dependensi spasial dengan uji Lagrange Multiplier (LM). Uji ini digunakan untuk mengetahui model mana yang terbaik. Hasil uji disajikan di Tabel 3. Uji LM dengan $\alpha=5 \%$ memberikan kesimpulan bahwa ada dependensi spasial pada variabel dependen atau diindikasikan model SAR lebih sesuai digunakan.

\begin{tabular}{|c|c|}
\hline Lagrange Multiplier & p-value \\
\hline $\mathrm{LM}_{\text {error }}$ & 0,0535 \\
\hline $\mathrm{LMl}_{\mathrm{ag}}$ & 0,0340 \\
\hline LM SARMA & 0,0897 \\
\hline
\end{tabular}

Hasil pemodelan SAR, SEM, dan SDM masing-masing disajikan pada Tabel 4, Tabel 5, dan Tabel 6. Ketiga model ini memberikan kesimpulan yang berbeda-beda. Hipotesis yang digunakan untuk menguji faktor-faktor yang mempengaruhi kasus DBD adalah hipotesis nol yang menyatakan variabel independen tidak mempengaruhi dan hipotesis alternatif yang menyatakan variabel independen mempengaruhi kasus DBD. Model SAR memberikan hasil bahwa jumlah tenaga medis $\left(\mathrm{X}_{1}\right)$ dan fasilitas kesehatan $\left(\mathrm{X}_{2}\right)$ tidak signifikan mempengaruhi kasus DBD. Namun, demikian parameter $\rho$ sebagai parameter koefisien spasial lag variabel dependen signifikan berpengaruh. Hal ini menunjukkan bahwa kasus DBD di suatu kecamatan memberikan pengaruh bagi kasus DBD di kecamatan lain. Model SEM juga memberikan hasil seperti model SAR, dimana variabel independen tidak signifikan mempengaruhi kasus DBD. Namun, parameter $\lambda$ sebagai parameter koefisien spasial lag error signifikan berpengaruh.

Tabel 4. Output Model SAR

\begin{tabular}{crrrc}
\hline Variabel & Koefisien & Std. Error & Zvalue & P-value \\
\hline Konstanta & 0,0114 & 0,0132 & 0,8676 & 0,3856 \\
$\mathrm{X}_{1}$ & $-0,0017$ & 0,0015 & $-1,005$ & 0,2711 \\
$\mathrm{X}_{2}{ }^{*}$ & 0,0083 & 0,0046 & 1,8106 & 0,0702 \\
$\rho^{*}$ & 0,7354 & 0,1487 & 4,9441 & $7,65 \times 10^{-07}$ \\
\hline \multicolumn{5}{c}{$\mathrm{AIC}=-75,755$} \\
\hline
\end{tabular}

*) signifikansi pada $\alpha=5 \%$ 
Tabel 5. Output Model SEM

\begin{tabular}{ccccc}
\hline Variabel & Koefisien & Std. Error & Zvalue & P-value \\
\hline Konstanta & 0,0412 & 0,0176 & 2,3361 & 0,0195 \\
$\mathrm{X}_{1}$ & $-0,0009$ & 0,0012 & $-0,7118$ & 0,4766 \\
$\mathrm{X}_{2}$ & 0,0062 & 0,0043 & 1,4319 & 0,1521 \\
$\lambda *$ & 0,68579 & 0,17268 & 3,9714 & $7,12 \times 10^{-05}$ \\
\hline \multicolumn{5}{c}{$\mathrm{AIC}=-74,47$} \\
\end{tabular}

*) signifikansi pada $\alpha=5 \%$

Model SDM memberikan hasil yang berbeda. Model ini memberikan kesimpulan bahwa semua variabel independen, lag variabel independen, dan lag variabel dependen signifikan mempengaruhi DBD. Nilai koefisien -0,0054 menunjukkan bahwa semakin tinggi jumlah tenaga medis di suatu kecamatan maka kasus DBD akan rendah. Secara geografi berdasarkan koefisien lag jumlah tenaga medis ( $\left.\operatorname{Lag} \mathrm{X}_{1}\right)$-0,0104 dapat disimpulkan bahwa suatu kecamatan akan memiliki kasus DBD rendah, jika bertetanggaan dengan kecamatan lain yang memiliki jumlah tenaga medis tinggi.

\section{Tabel 6. Output Spatial Durbin Model}

\begin{tabular}{ccccc}
\hline Parameter & Estimate & Std. error & Zvalue & P-value \\
\hline (intercept) & 0,1033 & 0,0497 & 2,0802 & 0,0375 \\
$\mathrm{X}_{1}{ }^{*}$ & $-0,0054$ & 0,0022 & $-2,4153$ & 0,0157 \\
$\mathrm{X}_{2} *$ & 0,0163 & 0,0059 & 2,7794 & 0,0054 \\
$\mathrm{Lag} \mathrm{X}_{1} *$ & $-0,0104$ & 0,005 & $-2,0715$ & 0,0383 \\
Lag $\mathrm{X}_{2} *$ & 0,0258 & 0,0126 & 2,0453 & 0,0408 \\
$\rho^{*}$ & 0,7132 & 0,15091 & 4,7264 & $2,29 \times 10^{-06}$ \\
\hline \multicolumn{5}{c}{$\mathrm{AIC}=-75,884$} \\
\hline
\end{tabular}

*) signifikansi pada $\alpha=5 \%$

Ketiga model SAR, SEM, dan SDM masing-masing memiliki nilai AIC -75,755; -74,47; dan -75,884. Sehingga model SDM lebih baik digunakan untuk menduga kejadian kasus Demam Berdarah Dengue (DBD) di kabupaten Bantul karena memiliki nilai AIC terkecil.

\section{KESIMPULAN}

Tenaga medis dan fasilitas kesehatan yang memadai akan membantu menurunkan angka DBD di Kabupaten Bantul sehingga masyarakat juga bebas DBD. Hal ini sesuai dengan hasil model SDM yang memberikan hasil bahwa tenaga medis dan fasilitas kesehatan signifikan mempengaruhi kasus DBD. Dari aspek spasial memberikan informasi bahwa kondisi geografi atau aspek lokasi juga mempengaruhi, dimana kasus DBD antar kecamatan yang berdekatan akan saling mempengaruhi. Suatu kecamatan akan memiliki kasus DBD tinggi jika 
berdekatan dengan kecamatan lain dengan kasus DBD tinggi. Seperti kecamatan-kecamatan yang berada di bagian selatan dan jauh dari pusat pemerintahan cenderung memiliki kasus DBD tinggi. Hal ini tentu memberikan informasi bahwa program-program pemberantasan DBD dapat dimulai dari lokasi tersebut, sehingga mampu menurunkan kasus DBD di lokasi sekitarnya.

\section{UCAPAN TERIMA KASIH}

Naskah ini merupakan salah satu luaran dari penelitian pada Program Kreatifitas Mahasiswa (PKM) yang diselenggarakan oleh Direktorat Jenderal Pembelajaran dan Kemahasiswaan, Kemenristek Dikti, Indonesia. Peneliti mengucapkan terimakasih atas dana yang diberikan dari Kemenristek Dikti serta IST AKPRIND Yogyakarta yang memberikan dukungan sarana dan prasarana.

\section{DAFTAR PUSTAKA}

Anselin, L. (2001). Spatial econometrics. A companion to theoretical econometrics, 310330.

Candra, A. (2010). Demam Berdarah Dengue: Epidemiologi, Patogenesis, dan Faktor Risiko Penularan. ASPIRATOR-Jurnal Penelitian Penyakit Tular Vektor (Journal of Vector-borne Diseases Studies), 2(2).

Huang, C.-C., Tam, T., Chern, Y.-R., Lung, S.-C., Chen, N.-T., \& Wu, C.-D. (2018). Spatial clustering of dengue fever incidence and its association with surrounding greenness. International journal of environmental research and public health, 15(9), 1869.

Kusuma, A. P., \& Sukendra, D. M. (2016). Analisis Spasial Kejadian Demam Berdarah Dengue Berdasarkan Kepadatan Penduduk. Unnes Journal of Public Health, 5(1), 48-56.

Rahman, S. A., Rahim, A., \& Mallongi, A. (2018). Risk analysis of dengue fever occurrence in bone province sulawesi south using temporal spatial geostatistical model. Indian Journal of Public Health Research \& Development, 9(4), 221-226.

Sintorini, M. M. (2007). Pengaruh iklim terhadap kasus demam berdarah dengue. Kesmas: National Public Health Journal, 2(1), 11-18.

Suryowati, K., Bekti, R., \& Faradila, A. (2018). A Comparison of Weights Matrices on Computation of Dengue Spatial Autocorrelation. Paper presented at the IOP Conference Series: Materials Science and Engineering.

Suyasa, I. G., Putra, N. A., \& Aryanta, I. R. (2008). Hubungan faktor lingkungan dan perilaku masyarakat dengan keberadaan vektor demam berdarah dengue (DBD) di wilayah kerja puskesmas I Denpasar Selatan. ECOTROPHIC: Jurnal Ilmu Lingkungan (Journal of Environmental Science), 3(1).

Triliani, S. E., \& Bekti, R. D. (2017). SPATIAL DURBIN MODEL UNTUK MENGIDENTIFIKASI FAKTOR-FAKTOR YANG MEMPENGARUHI PENGANGGURAN DI PROVINSI JAWA TENGAH. Jurnal Statistika Industri dan Komputasi, 2(02), 93-103. 
Metode Spatial Durbin Model Untuk Analisis Demam Berdarah Dengue Di Kabupaten Bantul Marthin Luter Laia, Rahmat Deswanto, Erma Shofi Utami, Rokhana Dwi Bekti

Waris, L., \& Yuana, W. T. (2013). Pengetahuan dan perilaku masyarakat terhadap demam berdarah dengue di kecamatan batulicin kabupaten tanah bumbu provinsi Kalimantan Selatan. Jurnal Buski, $4(3)$. 